\title{
Marine Pollution $73 / 78$ IMO convention: a tool for sustainable marine resources in Kepulauan Riau Province
}

\author{
Abdurrahman Zacky ${ }^{1}$, Dhani Akbar ${ }^{1 *}$, Agung Dhamar Syakti ${ }^{2}$ \\ ${ }^{1}$ International Relation, Universitas Maritim Raja Ali Haji, Tanjungpinang 29411, Indonesia \\ ${ }^{2}$ Marine and Fisheries Faculty, Universitas Maritim Raja Ali Haji, Tanjungpinang 29411, Indonesia
}

\begin{abstract}
Annual sludge oil mitigation in Kepulauan Riau is one of the government's efforts to comply with the results of the Convention of Marine Pollution (MARPOL) 73/ 78 IMO which is well-known as the basis of efforts to prevent pollution at ocean caused by economic activities at sea. This research aims to observe and evaluate the government effort to comply with the MARPOL 73/ 78 convention and its annual implementation response and mitigate illegal sludge oil activity in Kepulauan Riau Province. The data collection was carried out by sampling method to contaminated areas in Batam and Bintan as a locus of the research. Analysis of Green Theory, in the discipline of International Relations, conducted to provide a spotlight on environmental aspects in a sludge oil occurrence. The understanding of the concept of triangulation between environmental, economic, and state aspects is the basis for understanding the sludge oil issue, which is trying to be described through the perspective of global environmental ethics. It is shown that the overall efforts made by the government are in accordance with the MARPOL 73/78 and environmental analysis based on Green Theory. In conclusion, upcoming mitigation to be improved are appropriate budgeting, technology to response and prevent the occurrence, socialization and empowering coastal local communities, and optimizing regional collective responsibility and cooperation
\end{abstract}

\section{Introduction}

Kepulauan Riau Province is one of the provinces in Indonesia which is based onIslands. With an area of almost 96 percent consisting of water, the Kepulauan Riau is one of the areas that is focus in the maritime and maritime sector. In addition, the Kepulauan Riau is also one of the provinces located on the border between Indonesia and neighboring countries such as Singapore and Malaysia. The Kepulauan Riau is also one of the international trade areas where the Kepulauan Riau region is in the Malacca Strait which is one of the international trade routes and crowded with ships from abroad [1].

The Riau Islands is located in the most strategic sea trade route in Southeast Asia, namely the Malacca Strait and the Singapore Strait. The heavy shipping traffic in the Malacca Strait makes ships that cause several obstacles, including environmental pollution in the waters that have an impact on the waters of the Kepulauan Riau [2]. This can be detrimental to the Kepulauan Riau because of waste pollution making coastal areas in the Kepulauan Riau affected. Cooperative efforts made by coastal countries in the Malacca Strait to prevent environmental pollution due to oil spills have been carried out since 1971 [3]. This collaboration is known as the Tripartite Technical Experts Group (TEG) which was formed as a response to the issue of oil spills in the Malacca Strait. TEG has a focus on navigation security and environmental protection due to ship activities in the Malacca Strait which resulted in the provisions of the Traffic Separation Scheme (TSS), Under Keel Clearance (UKC). Then in 1999, Indonesia, Malaysia, and Singapore established Vessel Traffic Systems (VTS) and Ship Reporting System in the Straits of Malacca and Singapore (STRAITREP) as a form of cooperation in handling waste pollution issues in the Malacca Strait [4].

The problem occurs when the ship's obligation to clean the ship is set by the Singapore government. The price set by the Singapore government is considered too expensive, so some companies take other ways to avoid it. They deliberately dispose of the remaining oil on the ship by putting it in a sack which is filled with sand and then the sacks are thrown into the sea. As the basic nature of oil cannot mix with water, the oils in the sack float and then become lumps that pollute the surrounding waters. The fraudulent practices carried out by the crew of the ship have occurred many times in recent years [5]. As a result, the water area will be dirty up to the coast. This pollution is in the form of lumps of oil that float in the sea to the coast. This environmental pollution also damages the underwater ecosystem around the waters in the Kepulauan Riau. This pollution case generally occurs in the Kepulauan Riau but often occurs on the coast of Batam City and Bintan Regency because it is not far from Singapore [2].

As the results of the International Convention for The Prevention of The Pollution On Ships or known as the MARPOL 73/78 Convention, which is an

\footnotetext{
*Corresponding author: akbardhani@umrah.ac.id
} 
international convention that discusses the establishment of regulations as a form of prevention of environmental pollution at sea due to operational activities and accidents on ships (International Maritime Organization, nd). In the convention, the countries registered in the convention are obliged to comply with these regulations and responsible for all operations with ships that are flagged by that country. MARPOL 73/78 is an acronym for maritime pollution where the number 73 indicates the year the convention was signed and the number 78 is the year the convention was amended. MARPOL 73/78 was adopted by the International Maritime Organization (IMO) on 17 February 1973 but did not receive enthusiasm from member countries. Then in 1978, IMO adopted Tanker Safety Pollution Prevention or abbreviated as TSPP which was a response to the frequent occurrence of tanker accidents in the previous few years. Then the combination of the two regulations is known as MARPOL 73/78 which came into force on October 2, 1983 [6].

In Kepulauan Riau, there are several areas that are often polluted by maritime activities that occured, among the many pollutions that occur, our concentration is focused on oil spill pollution. Oil spills at sea that occur in Kepulauan Riau often occur due to the geographical location of Kepulauan Riau which is close to the Malacca Strait which is a world trade route. Many ships pass and not a few are polluting the sea. This activity should be a benchmark so that the Kepulauan Riau and Indonesian Provincial Governments can be more active in efforts to prevent oil pollution and it should be done considering Indonesia's commitment to preserving marine ecosystems and preventing oil pollution in the sea [2]. This study aims to determine whether law enforcement carried out by the Indonesian government is in accordance with aspects of environmental management related to the sludge oil problem in the Kepulauan Riau. From the results of this study, we can find out how the solution in handling environmental pollution problems in Indonesia refers to the MARPOL 73/78 convention and the application in the prosecution of sludge oil cases in Kepulauan Riau.

\section{Method}

This research used qualitative research with descriptive method. Researchers took two research locations as samples that can be used as an illustration in the study, namely Batam City and Bintan Regency. This research was conducted using data collection techniques in the form of observation, interviews, documentation and public discussions with informants as a source of data, totaling 10 people [7].

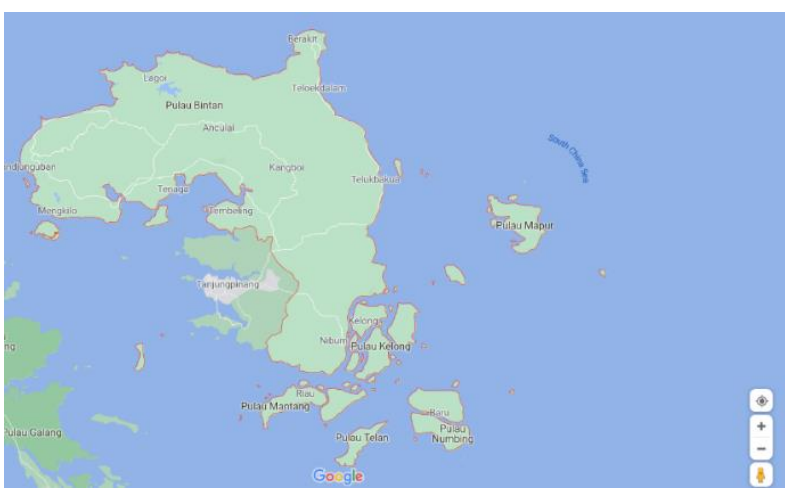

Figure 1. Research Location

\section{Result}

The density of shipping activities in the Malacca Strait and the Natuna Sea has an impact on the threat of environmental pollution in the waters of the Kepulauan Riau Province. Oil spills and toxic and dangerous chemicals are one of the dangerous threats to the preservation of aquatic ecosystems in the Kepulauan Riau Province. The threat of sludge oil that occurs in the waters of the Kepulauan Riau Province is a periodic pollution. This is because the pollution occurs periodically, in other words, it occurs in every north wind season. In this regard, the Government of Indonesia seeks to reduce marine pollution caused by ship operations as stipulated in MARPOL 73/78, through Presidential Decree no. 46 of 1986. Also, the government of the Kepulauan Riau Province through the Decree of the Governor of the Kepulauan Riau Province number 742 of 2018, on May 142018 has officially formed a regional team as a form of effort to overcome the problem of oil spills in the Kepulauan Riau Province.

The Regional Team as intended can act quickly, accurately and in a coordinated manner in preventing and overcoming the spread of oil spills at sea, as well as overcoming environmental impacts due to oil spills. The Regional Team is a combination of several regional agencies related to sludge oil problems that occurred in the Kepulauan Riau Province with the aim of facilitating coordination in carrying out security, prevention, and control of waste oil pollution that pollutes coastal areas in the Kepulauan Riau.

\section{Discussion}

In relation to the duties and functions of the regional team, the following are some of the regional team's policies and efforts in responding to the oil waste pollution incident that occurred in the Kepulauan Riau Province Forms of Regional Team Policies and Efforts,

- Coordinate efforts to control pollution and coastal and marine damagse, with the relevant $\mathrm{KL}$ as per Presidential Decree No. 109/2006 concerning Management of Emergencies Due to Oil Spills at Sea.

- Mitigation of Environmental Impacts due to Oil Spills. 
- Management of B3 waste from unknown sources that pollute the coast. (Cleaning, collection, transportation and disposal).

- $\quad$ Strengthening local government capacity.

- Encouraging increased monitoring and patrolling of oil spills.

- Increasing community participation through the implementation of coastal environmental restoration activities in the region.

In carrying out their duties, the regional team coordinates with the Marine Observation Research Center (BROL) of the Ministry of Marine Affairs and Fisheries Jembrana Bali. The cooperation carried out was to monitor the territorial waters of the Riau Islands Province through BROL's radar satellite which is carried out at coordinates 1040-105.020 East Longitude and 1020-2.20 North Latitude to obtain information on the distribution of oil spills. This monitoring activity can also be regarded as a form of regional security patrol carried out through satellite technology, to assist regional teams who are carrying out tasks in the field. The use of technology in handling sludge oil problems in Riau Islands can also help to identify ships that dump oil without a permit into the sea. This can be done using the oil sampling method, which is a method of taking oil samples from each ship that anchors and then recording data on the vessel and oil carried by the ship, so that when there is an incident of marine pollution due to an oil spill, the government can find out where the oil came from and know the ship that dumped the oil.

The alternative technology offered to optimize the handling of waste oil in Riau Islands is to use the bioremediation method, which is a method for managing oil-contaminated soil using micro-organisms as a tool. Thus, this process can remove oil content from contaminated soil and restore it naturally [12]. The government has also set a standard operating procedure or SOP to control and prevent oil pollution in the Riau Islands, the explanation is contained in List of SOPs that have been made by the government in the Riau Islands

- SOP on Law Enforcement against Ships that illegally anchor Lego in the Riau Islands.

- SOP regarding alleged violations of ships that do not activate the Automatic Identification System (AIS) in the waters of the Riau Islands.

- $\quad$ SOP on Ship Inspection by Port State Control.

- SOP on Searching for Ships of Illegal Oil Spill Actors using Satellite Image Technology, Oil Modeling, and AIS in Riau Islands Waters.

- SOP on Environmental Compliance Monitoring and services

- Hazardous Waste Management for Tank Cleaning Activities.

Furthermore, related to oil pollution also toxic and hazardous chemicals or B3, it is necessary to manage waste that has been cleaned, so that it can be utilized optimally. The Riau Islands Provincial Government through the Environment and Forestry Service has prepared a strategy in managing B3 waste in accordance with environmental sustainability procedures, including strengthening law enforcement aspects, strengthening capacity and institutions, developing science and technology, and increasing the role of the community. So that in managing waste oil requires the role of several actors from the government, related companies, academics, and local communities. With the cooperation of these actors, it is hoped that the management of sludge oil waste in the Riau Islands Province, especially in the Bintan and Batam areas, can be carried out optimally to provide benefits for ecological sustainability in Riau Islands [9].

The implementation of the MARPOL $73 / 78$ policy in the Riau Islands Province ineffort to prevent and deal with potential environmental pollution in the waters and coastal areas of Riau Islands has become a discussion that can be classified as a concept of environmental security. Environmental security or better known as Environmental Security is a concept that aims to determine the impact caused by state conflicts and international relations and their effects on environmental conditions and understand how environmental problems can move across national borders. The concept of environmental security began to become popular and developed rapidly in the 1990s. The development of the concept of environmental security is closely related to the concept of national security.

In relation to the sludge oil problem in Riau Islands, the environmental security view explains several relevant points regarding the relationship between environmental security and its effect on national security. The issue of sludge oil that occurs in the waters of the Riau Islands Province can be grouped into a nonmilitary threat to Indonesia's national security. It can be seen that the oil spill pollution that occurred in the Riau Islands Province may not occur on a large scale and does not occur regularly, so that it can be classified as an issue that is not given much attention, just as an explanation from an environmental safety point of view. However, if it is not handled optimally, this condition can have a prolonged effect on several elements in the Riau Islands Province. Threats posed by the sludge oil case can have an impact on several other aspects besides the environment, but also have an impact on health, economy, and even society.

In the perspective of the discipline of International Relations, Green theory is present and explains that there are three main aspects that are interrelated in a national development. The three aspects are the environment, the economy, and the state. In more detail, it is explained that in the concept of triangulation, environmental pollution can affect the economic condition of a country, then the economic instability can affect the development of the country. This is in line with the history of the implementation of the MARPOL 73/78 convention which started with accidents and ship operational events that often cause environmental pollution in waters and coastal areas.

The condition of the seas and beaches in the Riau Islands Province, which is polluted by this waste oil, causes economic losses, especially in the tourism sector in Riau Islands. It is known that the Riau Islands Province is one of the provinces in Indonesia that sells natural beauty and beaches as an attraction for tourists 
to visit there. However, this condition cannot be realized if the surrounding natural conditions are polluted. This results in economic losses. This also has an impact on the development of the Riau Islands where the budget allocated for handling the waste problem can be allocated as a budget for strengthening the tourism sector in Riau Islands. Green theory holds that an environmental pollution problem in a regional area is the responsibility of the countries around the regional area [10].

In effort to deal with environmental pollution problems in the Riau Islands Province, cooperation between institutions and related agencies is needed to solve the problem of waste pollution in the Riau Islands Province. Due to the geographical location of Riau Islands which is directly adjacent to Singapore and Malaysia, the responsibility for security must also be carried out at the central government level because this relates to national boundaries. The following MoUs between Indonesia and neighboring countries are described in the following to MoUs between Indonesia and neighboring countries regarding oil spills,

- MoU among the Government of Brunei Darussalam, Indonesia, Malaysia, Philippine, Singapore, and Thailand on Oil Spill Response Action Plan 1992.

- MoU among Government of Indonesia, Malaysia and Philippines on Sulawesi Sea Oil Spill Network Response Plan.

- MoU among the Government of Indonesia, Malaysia and Singapore on Standard Operating Procedure (SOP) for combating oil spill in the Straits of Malacca and Singapore.

- MoU between the Government of Indonesia and Australia on Oil Pollution Preparedness and Response 1996.

- MoU on ASEAN Cooperation Mechanism for Joint Oil Spill Preparedness and Response 2014.

Framework of cooperation in preventing oil waste in the Malacca Strait area is still inadequate, especially regarding the handling and prevention of the practice of intentionally disposing of waste oil. Indonesia, Malaysia and Singapore also established a Standard Operating Procedure (SOP) in dealing with oil spills from ships in the Malacca Strait. At the regional level, ASEAN member countries agreed on a Memorandum of Understanding (MOU) of the ASEAN Association of Southeast Asian Nation Oil Spill Response Action Plan (ASEAN OSRAP) related to cooperation in handling oil spills in Southeast Asia [4]. The purpose of this cooperation is to increase the capabilities and cooperation of ASEAN countries when dealing with the oil spill disaster.

All regulations and cooperation that have been carried out by the government will not work well if the awareness and support from the local community is still lacking. Communities on the coast of Riau Islands who are affected by the oil spill problem think that the oil spill problem is a traditional problem that must be solved by using the role of the state apparatus. This also illustrates the public's trust in the apparatus to be able to resolve the oil spill problem. Looking at the theory of global justice, it has the view that individuals have an important role as a reference for the state in determining a policy. If this view can be analyzed in relation to the issue of the oil spill in the Riau Islands, it is also necessary for the participation of the community in helping to deal with the problem of the oil spill that occurred in the Riau Islands.

Based on data from the Riau Islands Province DLHK, there have been efforts to deal with the sludge oil problem involving the participation of the community but it is felt that they have not solved the problem fundamentally. Handling the sludge oil issue in Riau Islands is nothing, but an effort to preserve the aquatic and coastal environment which is in line with the concept of a sustainable development program promoted by the United Nations in point 14 about underwater life where pollution occurs in waters and coasts directly or indirectly will have an impact on the underwater ecosystem which is very risky for a sustainable development. Until now, the Government of Indonesia continues to seek solutions to the remaining non-recyclable waste. Equipment is needed to be able to separate the waste from contaminated objects, so that there is still use value from the waste if it has been recycled [3].

\section{Conclusion}

The form of government compliance in protecting the waters in the Riau Islands Province has been carried out optimally. This is related to the form of policy carried out by the Riau Islands government which is based on the implementation of the MARPOL 73/78 convention in Indonesia. Through the green theory paradigm, the form of compliance of the Riau Islands provincial government in dealing with the sludge oil issue exceptionally. However, there are still some things that need to be improved. More focus is needed on environmental authorities aimed at strengthening institutional arrangements among stakeholders. This collaboration includes the government, business people, academics, NGOs, and the community who work together to maintain institutional arrangements related to the environment. In addition, the Riau Islands provincial government needs to work hard to optimize the handling of oil spills in the waters, namely budget and equipment problems, this can be seen from the ability of the Riau Islands local government to carry out the monitoring process of ships disposing of waste in waters that are less than optimal due to these two obstacles.

\section{References}

1. Kementerian Kelautan dan Perikanan, (n.d.).

2. D. Akbar, A. Setiawan, R. Prayuda, A. Putra, A. Aznor, and W. E. Yudiatmaja, Journal of Physics: Conference Series 1655, (2020). 
3. A. D. Syakti, F. Idris, C. J. Koenawan, R. Asyhar, and T. Apriadi, Egyptian Journal of Aquatic Research 45, 117 (2019).

4. A. Aznor, JSTOR 13 (2020).

5. A. D. Syakti, M. Jacob, T. Birrien, M. P. Suhana, M. Y. Aziz, A. Salim, P. Doumenq, and G. Louarn, Marine Pollution Bulletin 149, 110609 (2019).

6. International Maritime Organization, (n.d.).

7. Prof. Dr. Sugiyono, Metode Penelitian Pendidikan: Pendekatan Kuantitatif, Kualitatif, Dan $R \& D$ (2016).

8. A. D. Syakti, M. Jacob, T. Birrien, M. P. Suhana, M. Y. Aziz, A. Salim, P. Doumenq, and G. Louarn, Marine Pollution Bulletin 149, 110609 (2019).

9. W. E. Yudiatmaja, Yudithia, T. Samnuzulsari, and Suyito, IOP Conference Series: Earth and Environmental Science 423, (2020).

10. Christian. McGlinchey, Stephen, Walters, Rosie, Scheinpflug, International Relation Theory (2017).

11. A. Aznor, JSTOR 13 (2020).

12. A. D. Syakti, F. Idris, C. J. Koenawan, R. Asyhar, and T. Apriadi, Egyptian Journal of Aquatic Research 45, 117 (2019). 